This report was prepared as an account of work sponsored by an agency of the United States Government. Neither the United States Government nor any agency thereof, nor any of their employees, makes any warranty, express or implied, or assumes any legal liability or responsibility for the accuracy, completeness, or usefulness of any information, apparatus, product, or process disclosed, or represents that its use would not infringe privately owned rights. Reference herein to any specific commercial product, process or service by trade name, trademark, manufacturer, or otherwise does not necessarily constitulc or imply its endorsement, recommendation, or favoring by the United States Government or any agency thereof. The views and opinions of authors expressed herein do not necessarily state or reflect those of the United States Government or any agency thereof.

\title{
HIGH RESOLUTION, SHALLOW SEISMIC REFLECTION SURVEY OF THE PEN BRANCH FAULT (U)
}

by

\author{
A. Stieve \\ Westinghouse Savannah River Company \\ Savannah River Site \\ Aiken, South Carolina 29808
}

A Technical Report for publication

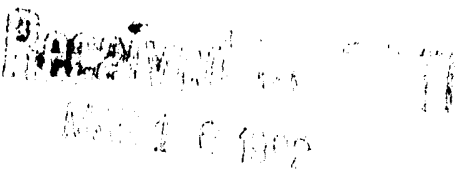

This report was prepared in connection with work done under Contract No. DE-AC09-89SR18035 with the U.S. Department of Energy. By acceptance of this paper, the publisher and/or recipient acknowledges the U.S. Government's right to retain a nonexclusive, royalty-free license in and to any copyright covering this paper, along with the right to reproduce and to authorize others to reproduce all or part of the copyrighted paper. 


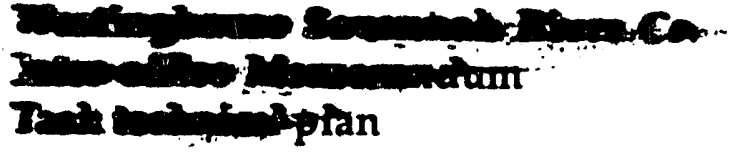

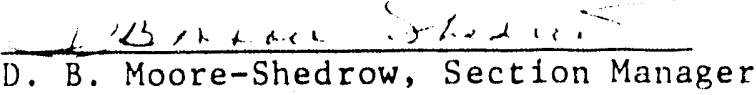

Authorized Derivative Classifer

May 15, 1991

To:

D. S. Kaback, group manager

From:
WSRC-RP-91-543

keywords: seismic reflection, fault, geology

\section{TITLE: HIGH-RESOLUTION, SHALLOW SEISMIC REFLECTION SURVEY OF THE PEN BRANCH FAULT.}

\section{Introduction}

The purpose of this project was to acquire, process, and interpret $28 \mathrm{~km}$ (17.4 miles) of high resolution seismic reflection data taken across the trace of the Pen Branch fault and other suspected, intersecting north-south trending faults. The survey was optimized for the upper $300 \mathrm{ft}$ of geologic strata in order to demonstrate the existence of very shallow, flat lying horizons, and to determine the depth to the fault or to sediments deformed by the fault. Field acquisition and processing parameters were selected to define small scale spatial variability and structural features in the vicinity of the Pen Branch fault leading to the definition and the location of the Pen Branch fault, the shallowest extent of the fault, and the quantification of the sense and magnitude of motion. Associated geophysical, borehole, and geologic data were incorporated into the investigation to assist in the determination of optimal parameters and aid in the interpretation.

\section{Discussion}

The SRS is located on the Atlantic Coastal Plain, which is an essentially flat-lying, undeformed wedge of unconsolidated marine and fluvial sediments. The sediments are stratified sand, clay, limestone, and gravel that dip gently seaward and range in age from Late Cretaceous to Recent. The sedimentary sequence thickens from zero at the Fall Line to more than 4,000 feet at the coast. There are about 600 to 1,200 feet of Coastal Plain sediments at SRS. The Coastal Plain section is divided into several groups based principally on age and lithology.

Beneath the Coastal Plain section is a pre-Cretaceous unconformity that developed on a basement consisting of two geologic terranes; 1) Triassic-Jurassic rift basin, the Dunbarton basin, filled with lithified terrigenous and lacustrine sediments with minor amounts of mafic volcanic and intrusive rock (Marine, 1974; Marine and Siple, 1974) and 2) crystalline terrane of metamorphosed sedimentary and igneous rock that may range in age from Precambrian to late Paleozoic. 
Westinghouse Savannah River Co. Inter-office Memorandum

Task technical plan

WSRC-RP-91-543

keywords: seismic reflection, fault, geology

May 15, 1991

To: $\quad$ D. S. Kaback, group manager

From: $\quad$ A. Stieve, task leader $\quad G \cdot \mathcal{Z} \cdot \mathcal{J}_{-}$

TITLE: HIGH-RESOLUTION, SHALLOW SEISMIC REFLECTION SURVEY OF THE PEN BRANCH FAULT.

\section{Introduction}

The purpose of this project was to acquire, process, and interpret $28 \mathrm{~km}$ (17.4 miles) of high resolution seismic reflection data taken across the trace of the Pen Branch fault and other suspected, intersecting north-south trending faults. The survey was optimized for the upper $300 \mathrm{ft}$ of geologic strata in order to demonstrate the existence of very shallow, flat lying horizons, and to determine the depth to the fault or to sediments deformed by the fault. Field acquisition and processing parameters were selected to define small scale spatial variability and structural features in the vicinity of the Pen Branch fault leading to the definition and the location of the Pen Branch fault, the shallowest extent of the fault, and the quantification of the sense and magnitude of motion. Associated geophysical, borehole, and geologic data were incorporated into the investigation to assist in the determination of optimal parameters and aid in the interpretation.

\section{Discussion}

The SRS is located on the Atlantic Coastal Plain, which is an essentially flat-lying, undeformed wedge of unconsolidated marine and fluvial sediments. The sediments are stratified sand, clay, limestone, and gravel that dip gently seaward and range in age from Late Cretaceous to Recent. The sedimentary sequence thickens from zero at the Fall Line to more than 4,000 feet at the coast. There are about 600 to 1,200 feet of Coastal Plain sediments at SRS. The Coastal Plain section is divided into several groups based principally on age and lithology.

Beneath the Coastal Plain section is a pre-Cretaceous unconformity that developed on a basement consisting of two geologic terranes; 1) Triassic-Jurassic rift basin, the Dunbarton basin, filled with lithified terrigenous and lacustrine sediments with minor amounts of mafic volcanic and intrusive rock (Marine, 1974; Marine and Siple, 1974) and 2) crystalline terrane of metamorphosed sedimentary and igneous rock that may range in age from Precambrian to late Paleozoic. 
The Pen Branch fault is a recently discovered feature in the Coastal Plain and basement at SRS. A program has been underway since January 1989 to evaluate the ability of this fault to release seismic energy (earthquake energy).

Because the PBF is located near operating nuclear facilities, public perception and federal regulations indicate that a thorough investigation of the fault is appropriate to determine whether any seismic hazard exists.

A phased program has been developed to investigate the PBF and to satisfy NRC regulatory quidelines represented in $10 \mathrm{CFR} 100$ Appendix $\mathrm{A}$. The program will be conducted over a period of 3 years. The objectives of the PBF program are to fully characterize the nature of the PBF.

Siting of nuclear reactors, as regulated in Appendix A of 10 CFR 100, requires identification of any faults with seismic potential in the region and in the vicinity of the nuclear facility. SRS is not required to comply with NRC regulations, but does follow the regulations as guidelines for siting and safety analysis of SRS facilities. SRS has used four criteria to establish the specific objectives for the PBF program.

The four criteria outlined in 10 CFR 100 Appendix A which define a "capable fault" as a fault likely to release large amounts of accumulated elastic strain energy as earthquakes include:

- criterion of recent or continual movement

- criterion of direct relation to "felt" earthquakes

- criterion of direct relationship to a known capable fault.

- criterion given for non-capability for faults that are associated with geologically very old structures

Due to the complexity and sensitivity of the PBF investigation program, a review committee of outside experts has been established (ESAC). They assist us in program design and data interpretation. Major program elements are carried out with the advice and consent of this group. Representation comes from academe, industry, and government.

\section{Task Description}

Customers. Environmental Sciences Section(ESS) originally proposed this investigation and also funded it. ESS is the customer.

Task deliverables. Deliverable items include final report, vertical seismic profile report, full scale seismic lines, all raw, intermediate, and final data, magnetic tapes, consulting services.

Task requirements. All deliverables are subject to the approval of the task leader. 


\section{Task prerequisites}

key parameters.

1. technical background of personnel

2. equipment

3. acquisition parameters

accuracy of measurements.

Not applicable because this is a remote sensing technique.

\section{Task Activities}

1) Procurement of services from a vendor experienced in seismic reflection acquisition, processing, and interpretation.

2) Site use and site clearance permits

3) Safety and security training of seismic acquisition personnel

4) Contraband passes for shot gun shells, buffalo gun, radios and machete knives.

5) Work Clearance Permit

a. $T$ \& $T$ clears the area for the survey line

b. surveyor flags in the line

c. E \& I suryeys the line for buried cables

d. Seismic crew shots the line

6) Receipt of raw, intermediate, and final data

7) Receipt of draft report

8) Receipt of final report

9) Close out contract

\section{References}

Balch, A. H., Lee, M. W., Miller, J. J., and Ryder, R. T., 1982, The use of vertical seismic profiles in seismic investigations: Geophysics, v. 47, n. 6, p. 906-918, 17 figures.

Berkman, E., 1990, Proposal to provide services for the high resolution seismic survey of of the Pen Branch Fault: Prepared in response to Solicitation Number A55978A, Westinghouse Savannah River Company, Aiken, South Carolina.

Berkman, E., 1991, High Resolution Seismic survey, Pen Branch Faultl, Savannah River Site, South Carolina, WSRC-TR-91-38, Savannah Rivere Site, Aiken South Carolina. 
Berteussen, A. K., and Ursin, B., 1983, Approximate computation of the acoustic impedance from seismic data: Geophysics, v. 48, n. 10, p. 1351-1358, 5 figures, 1 table.

Castagna, J. P., Batzle, M. L., and Eastwood, R. L., 1985, Relationships between compressional-wave and shear-wave velocities in clastic silicate rocks: Geophysics, v. 50, n. 4, p. 571-581, 25 figures, 2 tables.

Chacko, S., 1989, Porosity identification using amplitude versus offset: Geophysics, v. 54, n. 8, p. 942-951, 11 figures.

Chapman, W. L., and Di Stefano, M. P., 1989, Savannah River Plant Seismic Survey, 1987-88: Conoco Inc., Seismic Acquisition Section, Research Report 1809-005-006-1$89,110 \mathrm{p}$.

Code of Federal Regulations, 10 CFR 100 Appendix A, 1982, Seismic and geologic siting criteria for nuclear power plants: Office of the Federal Register, National Archives and Records Administration.

Cunningham, A. B., 1974, Refraction data from single-ended refraction profiles: Geophysics, v. 39, n. 3, p. 292-301, 7 figures.

Dobrin, M. B., 1976, Introduction to Geophysical Prospecting: McGraw-Hill, New York.

Fry, R. C., and Orange, A. S., 1982, High Resolution Seismic: A Practical Approach to Coal Exploration: Fifth Symposium on the Geology of Rocky Mountain Coal Proceedings, Claus Kurgel, Editor.

Lavergne, M., and Willm, C., 1977, Inversion of seismograms and pseudo velocity logs: Geophysical Prospecting, v. 25, p. 231-250.

Lewkowicz, J. F., Reischman, R., and Walsh, J. J., 1983, Results from open hole and cased hole vertical seismic profiles: SPWLA Twenty Fourth Annual Logging Symposium, June 27-30, 1983.

Lindseth, R. O., 1979, Synthetic sonic logs - A process for stratigraphic interpretation: Geophysics, v. 44, n. 1, p. 3-26, 22 figures.

Marine, I. W. , 1976, Structural and sedimentational model of the buried Dunbarton Triassic basin, South Carolina and Georgia, DP-MS-74-39, Savannah River Site, Aiken, South Carolina.

Marine, I. W., 1974, Geohydrology of a Buried Triassic Basin at Savannah River Plant, South Carolina: AAPG Bull. v. 58 p. 1825-1837.

Marine, I.W., and Siple, G.E., 1974, Buried Triassic basin in the central Savannah River area, South Carolina and Georgia: Geological Society of America Bulletin, v. 85, p.311-320. 
Marine,I. W., 1974b, Geohydrology of the buried Triassic basin at the Savannah River Plant, Groundwater, vol12, $96 \mathrm{pp}$.

Miller, R. D., Pullan, S. E., Waldner, J. S., and Haeni,F. P., 1986, Field comparison of shallow seismic sources: Geophysics, v. 51, n. 11 p. 2067 - 2092, 30 figures, 1 table.

Murdock, J. S., 1982, Preliminary Safety Analysis Defense Waste Processing Facility: E. I. du Ponte de Nemours and Co., Savannah River Laboratory, DPST-82-675, 4 volumes, prepared for the DOE under contract DE-AC09-76SR00001.

Musgrave, A. W. (Ed.), 1967, Seismic Refraction Prospecting: Society of Exploration Geophysicists, Tulsa, Oklahoma.

Petersen, T. A., L. D. Brown, F. A. Cook, S. Kaufman, and J. E. Oliver, 1984, Structure of the Riddleville Basin from COCORP seismic data and implications for reactivation tectonics. Journal of Geology, v. 92, pp. 261-271.

Price, V., and Cumbest, R., 1991, submitted to the GSA Bulletin.

Price, V., Steele, J., Stieve, A., 1989, Pen Branch Fault Investigation Program Plan, ESS-SRL-89-395.

Pullan, S. E., and H. A. MacAulay, H. A., 1987, An in-hole shotgun source for engineering seismic surveys: Geophysics, v. 52, n. 7 p. 985 - 996, 9 figures.

Siple, G.E., 1967, Geology and ground water of the Savannah River Plant and vicinity, South Carolina: U.S. Geological Survey Water Supply Paper No. $1841,113 \mathrm{p}$.

Snipes, D. S., Fallaw, W. C., Price, Jr., V., 1989, The Pen Branch Fault: Documentation of Late Cretaceous-Tertiary faulting in the Coastal Plain of South Carolina (U), Westinghouse-SRS, DP-MS-88-219.

Stephenson, D. E., 1988, August 1988 Savannah River Plant Earthquake: E. I. du Pont de Nemours \& Co., Savannah River Laboratory, Aiken, South Carolina, DPST-88-841, p. 1-12, 6 figures.

Stephenson, D. E., 1988, August 1988 Savannah River Plant Earthquake: E. I. du Pont de Nemours \& Co., Savannah River Laboratory, Aiken, South Carolina, DPST-88-841, p. 1-12, 6 figures.

Stephenson, D. E., Talwani, P., and Rawlins, J., 1985, Savannah River Plant Earthquake of June 1985: E. I. du Pont de Nemours \& Co., Savannah River Laboratory, Aiken, South Carolina, DPST-85-583, p. 1-31, 13 figures, 2 tables.

Stephenson, D. S. and Chapman, W. L., 1988, Structure associated with the buried Dunbarton basin, South Carolina from recent seismic data. Geological Society of America, Southeastern Section Abstracts with Programs, v. 20, p 318. 
Stephenson, D. S., and Acree, J., 1989, Presentation at Lawrence Livermore Information Dissemination Meeting for Seismic Hazards Study, Seismicity Panel, Hilton Head, South Carolina.

Talwani, P., Rawlins, J. and Stephenson, D. E., 1985, The Savannah River Plant, South Carolina, earthquake of June 9, 1985 and its tectonic setting, Earthquake Notes, v. 56 no. 4, p. 101-106.

Taner, M. T., and Koehler, E., 1981, Surface-consistent corrections: Geophysics, v. 46, p. 17-22.

Woods, J. P., 1952, Up-Hole Times: Geophysics, v. 17, n. 2, p. 229-235, 7 figures.

Wuenshel, P. C., 1960, Seismogram synthesis including multiples and transmission coefficients: Geophysics, v. 25, n. 1 p. 106-129, 11 figures.

Wyatt, K. D., 1981, Synthetic vertical seismic profile: Geophysics, v. 46, n. 6, p. 880-891, 17 figures, 2 tables.

Yu, G., 1985, Offset-amplitude variation and controlled amplitude processing: Geophysics, v. 50, n. 12, p. 2697-2708, 15 figures.

\section{Signatures}

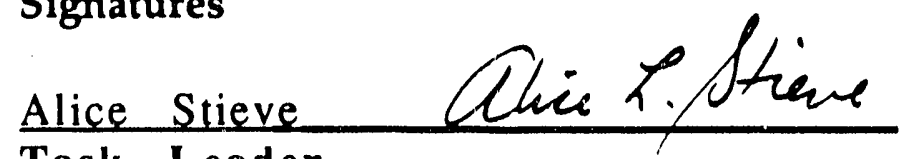

Task Leader

Llawn H. Kaback

Group Manager

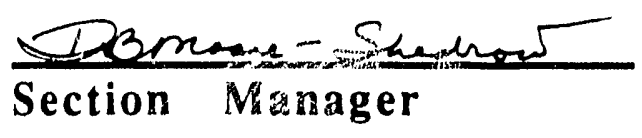

$6 / 17 / 91$

Date

$\frac{8 / 5 / 91}{\text { Date }}$

Date 


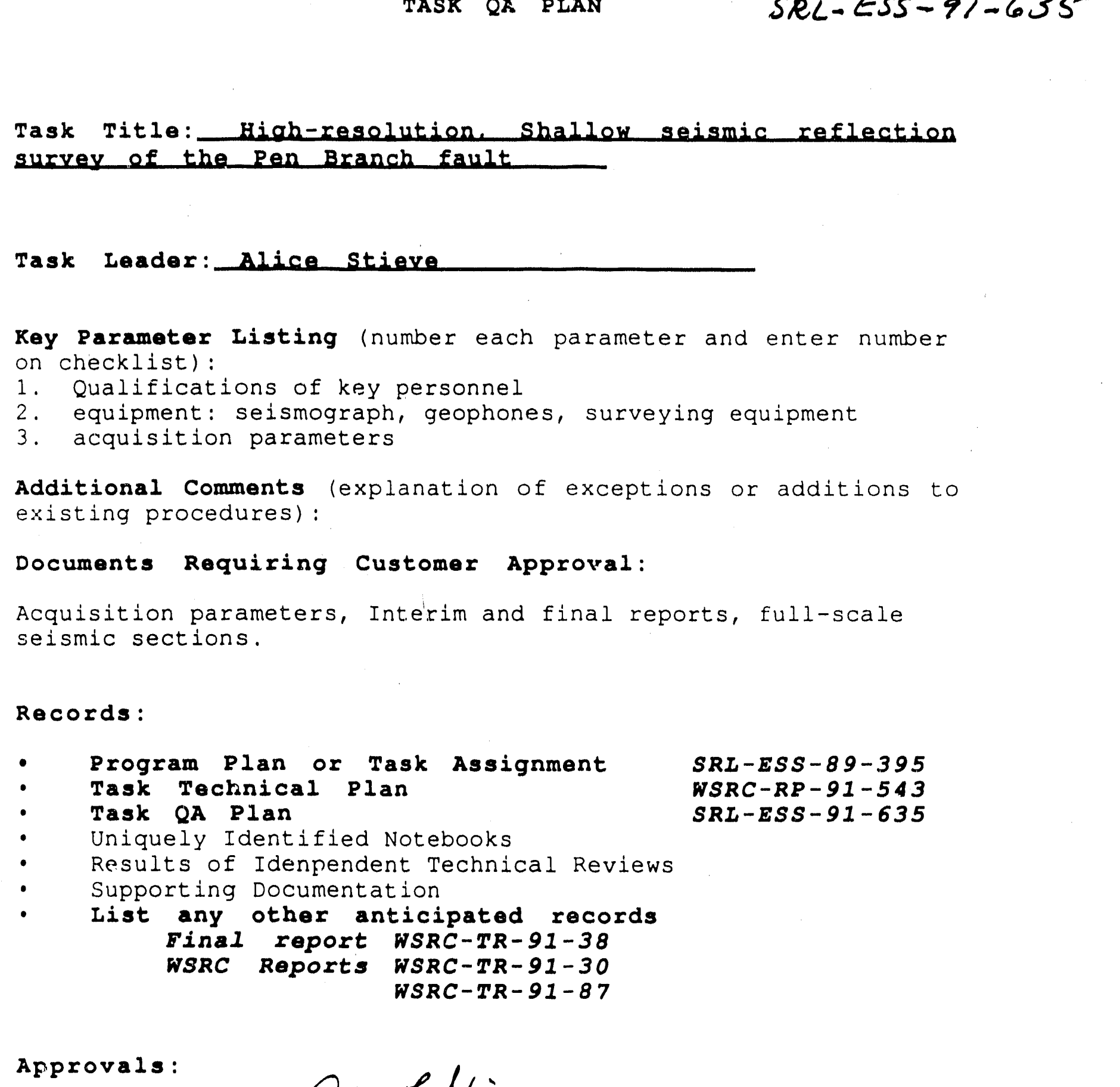

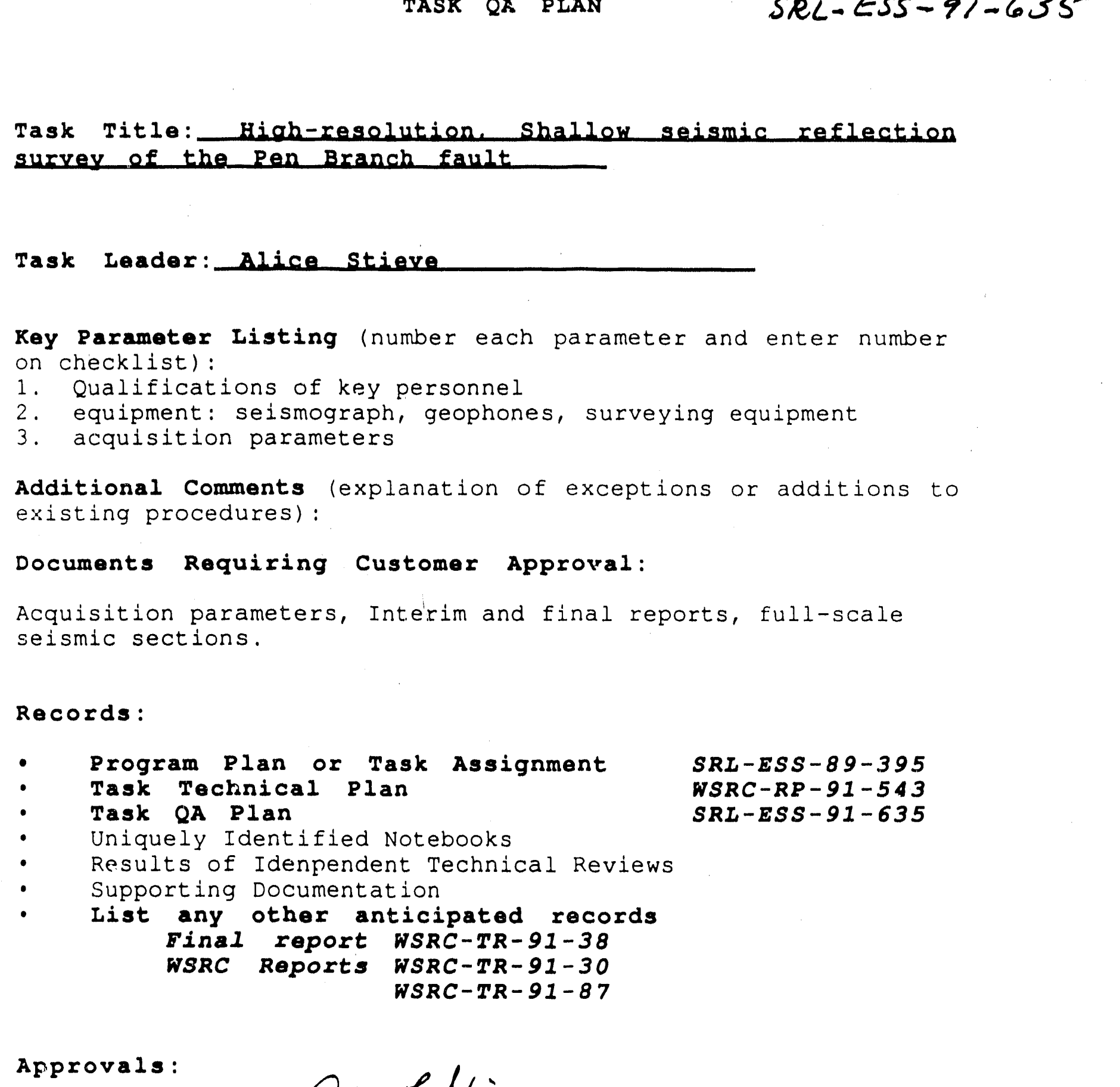

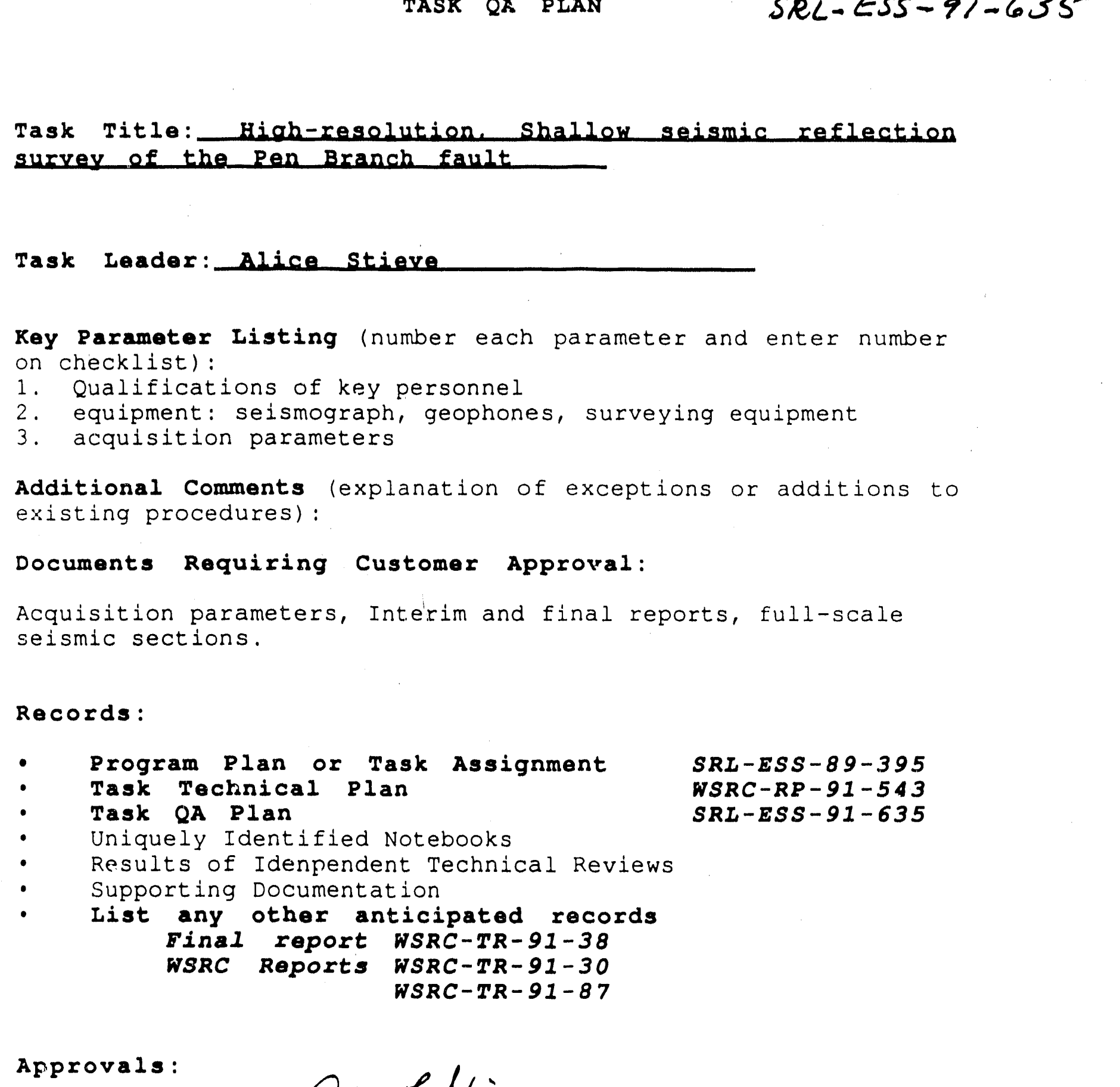

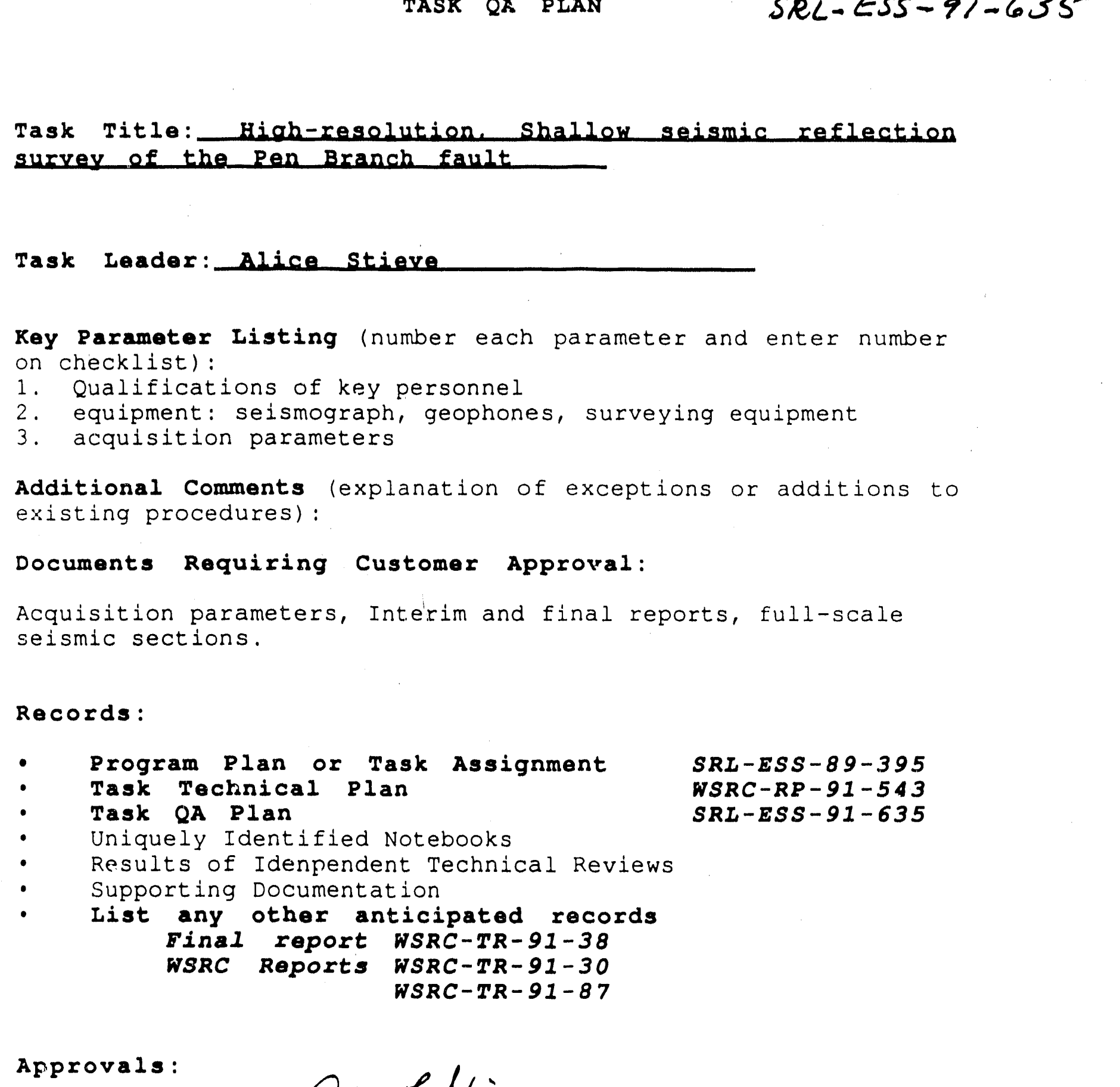

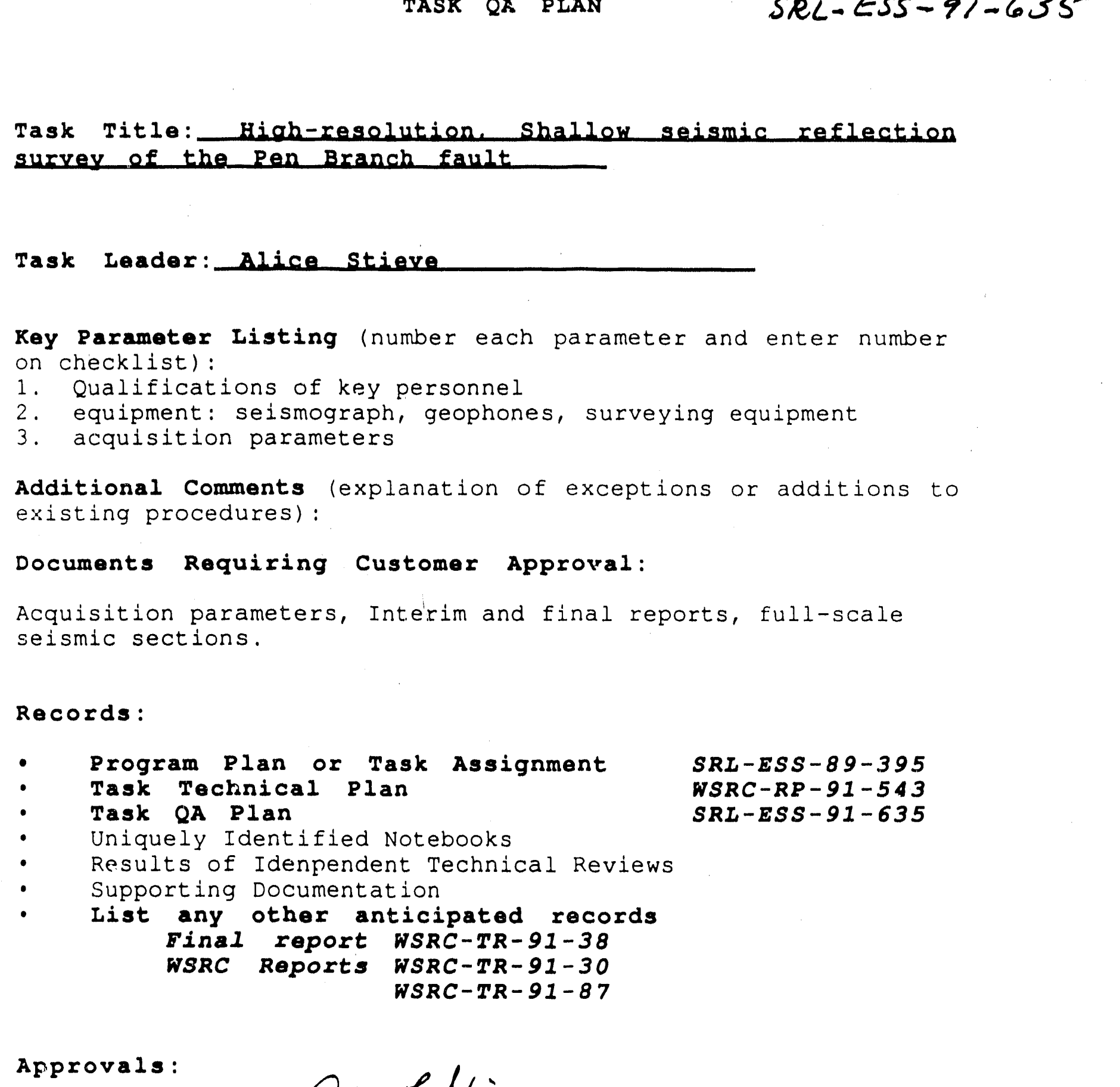

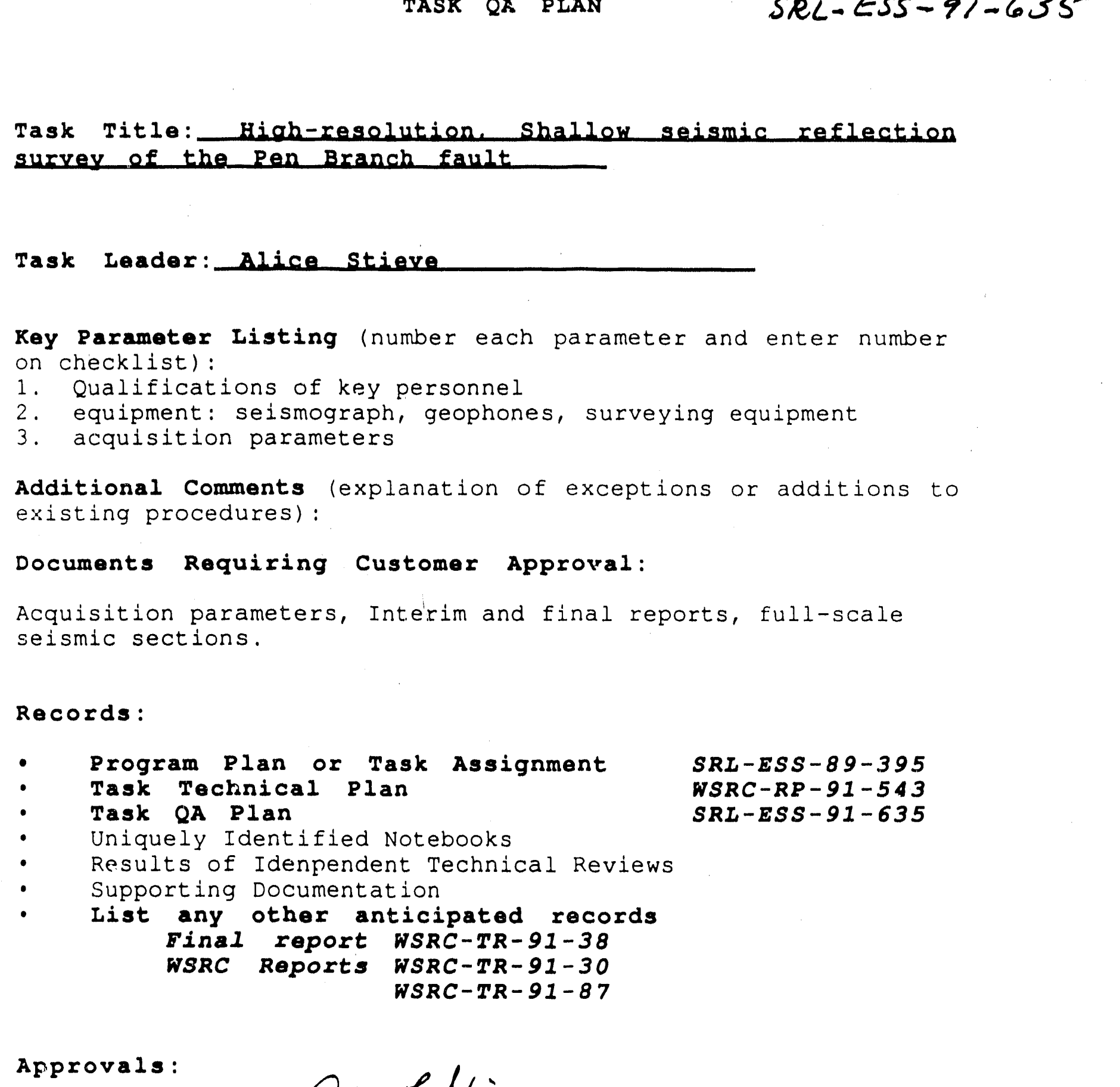

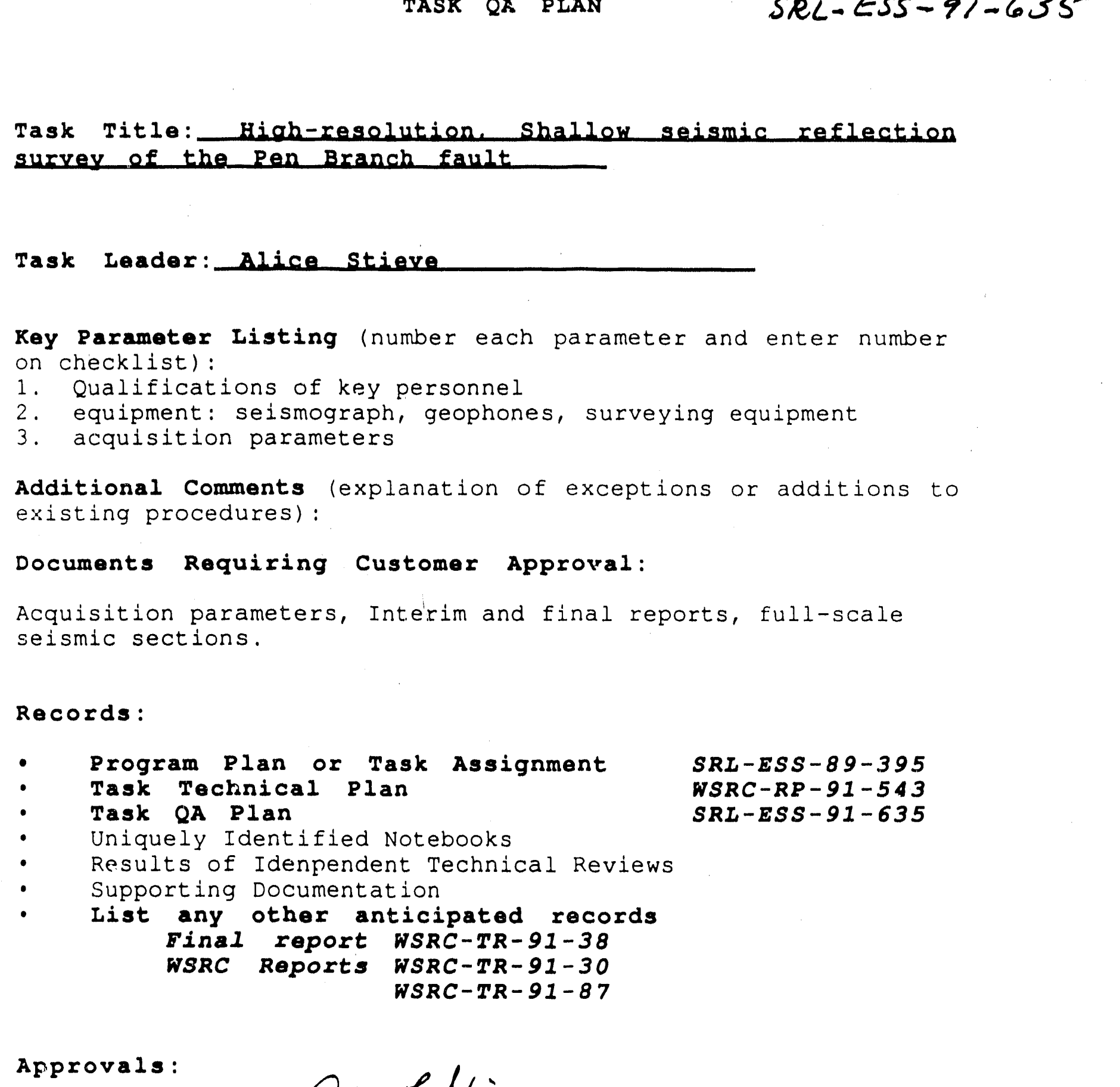

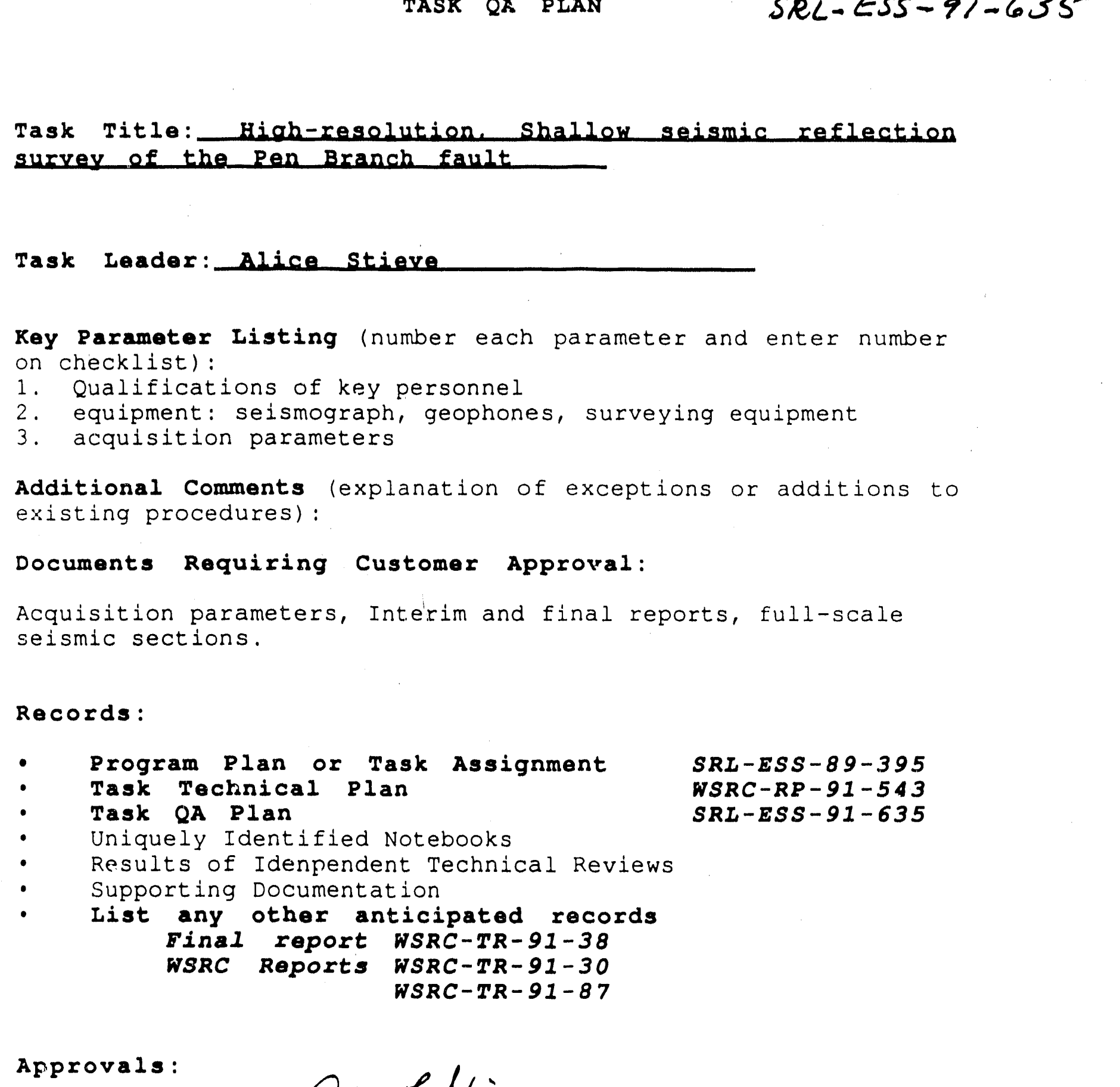

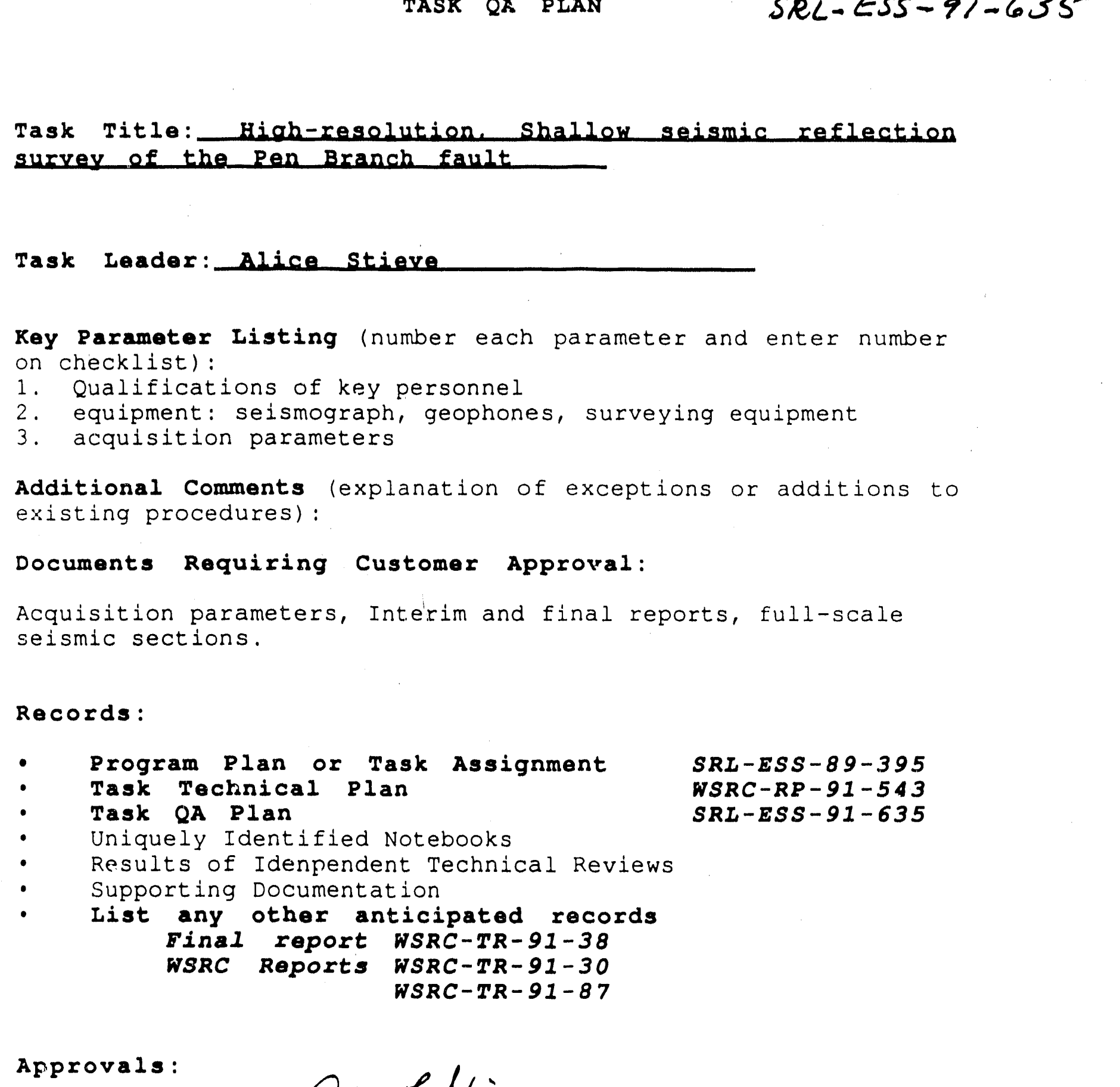

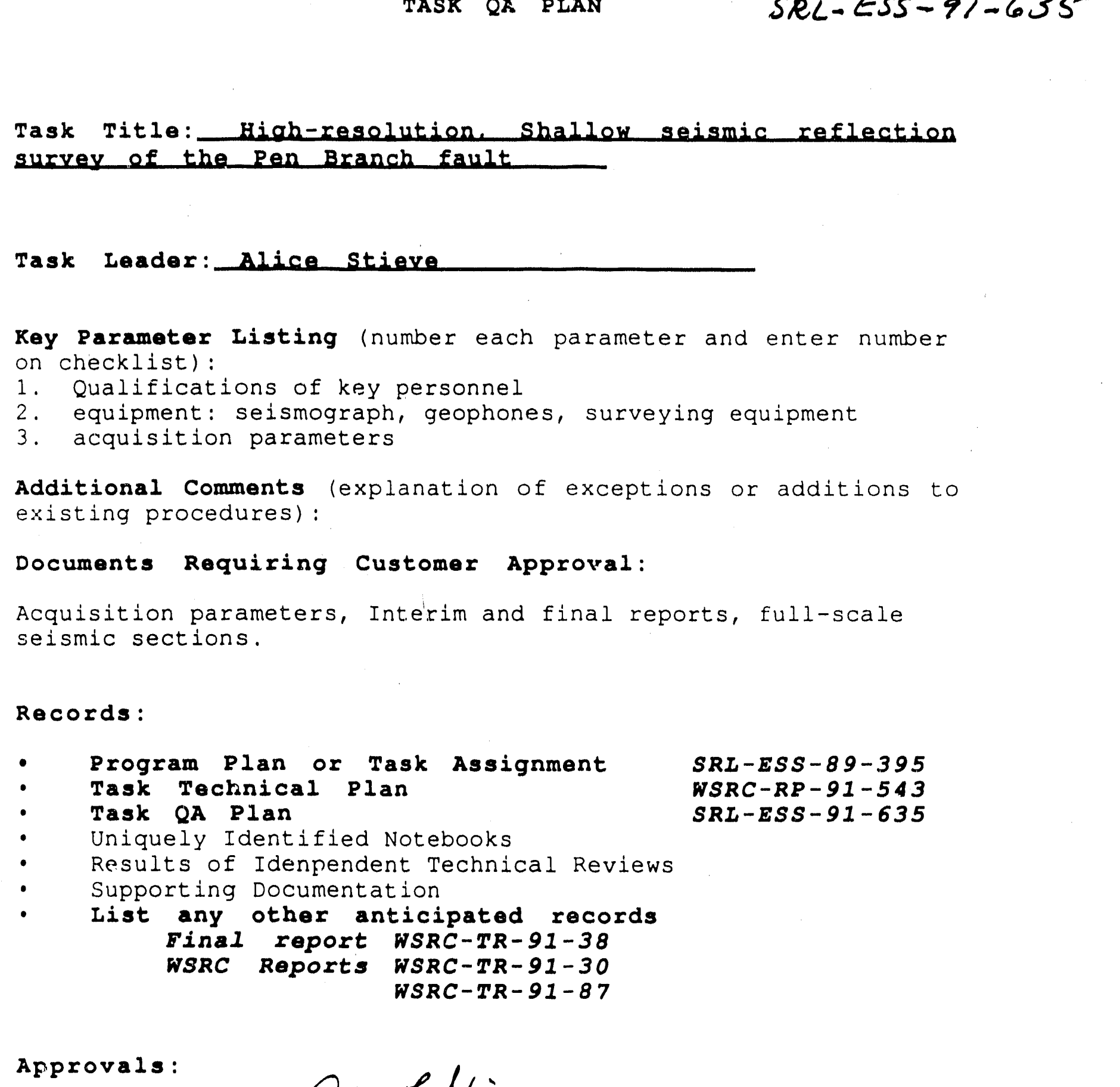

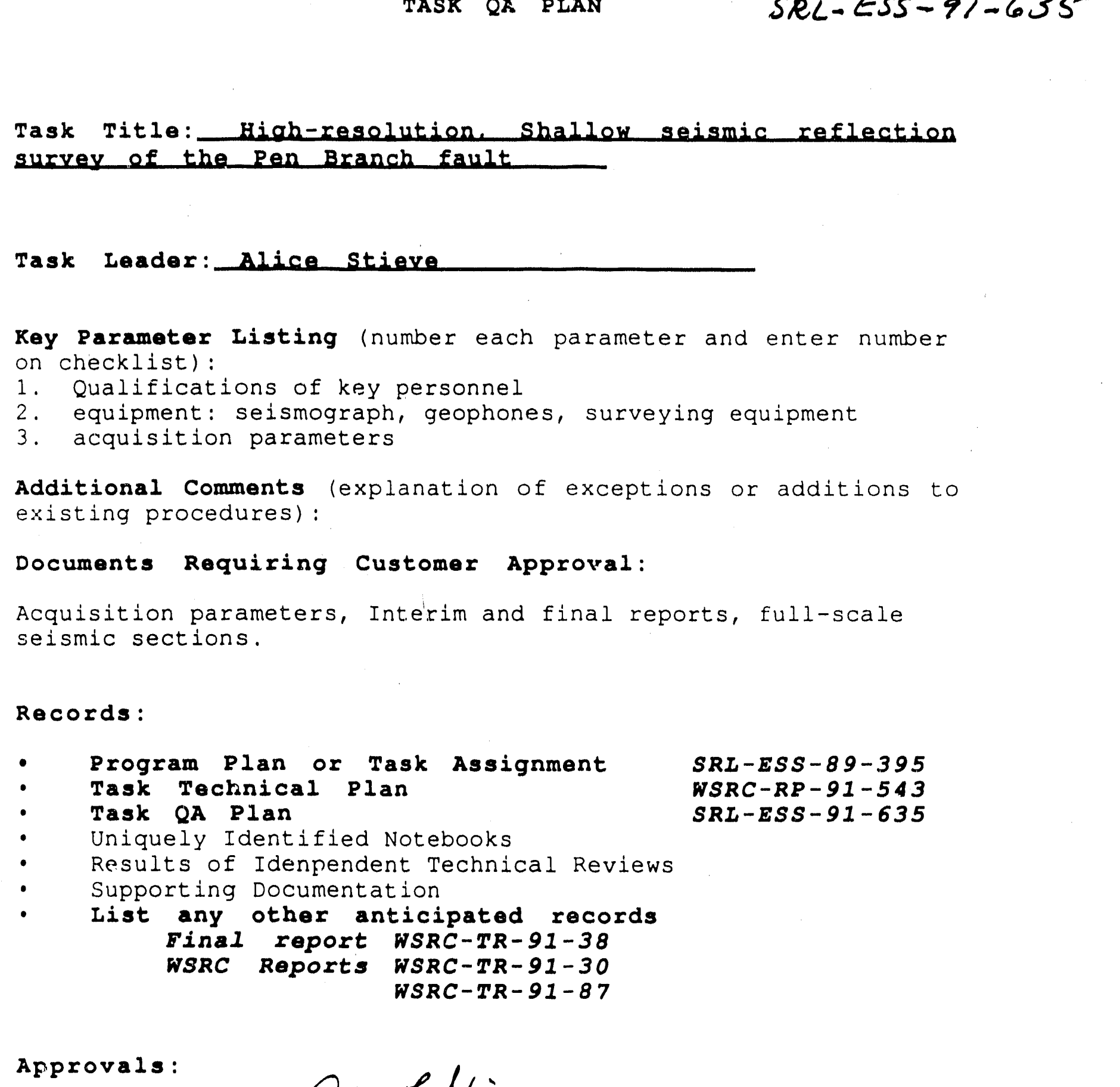

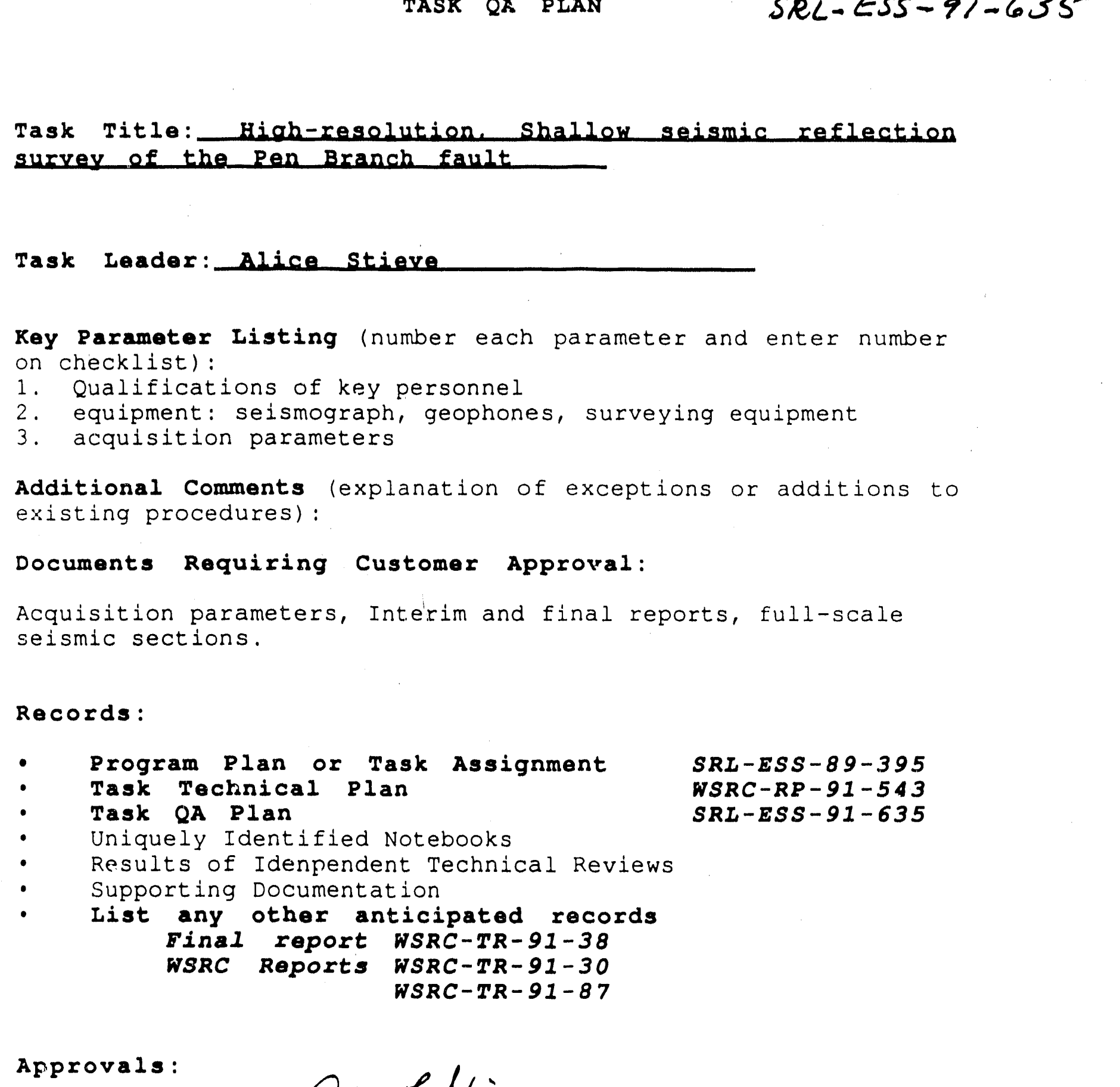

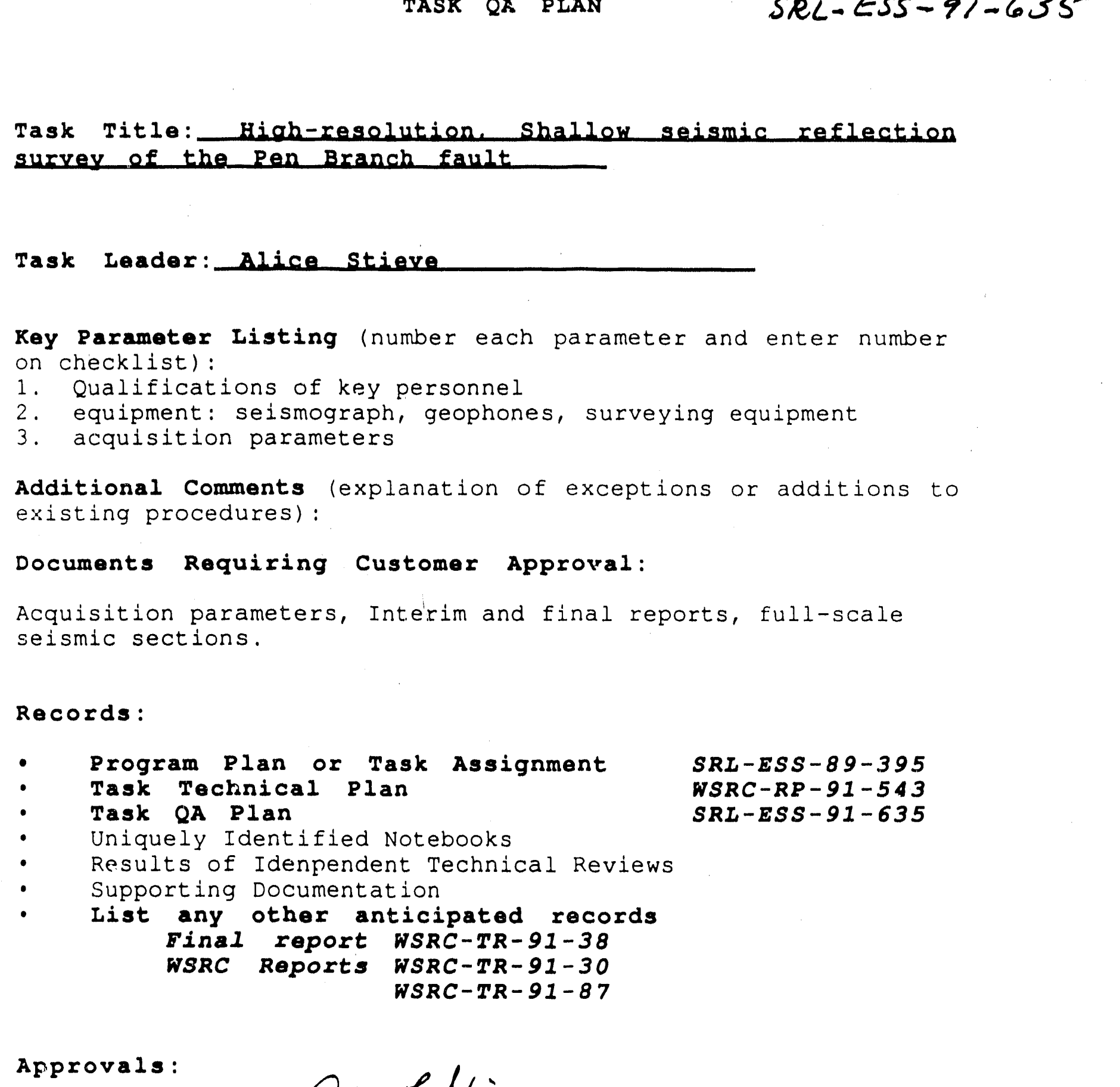

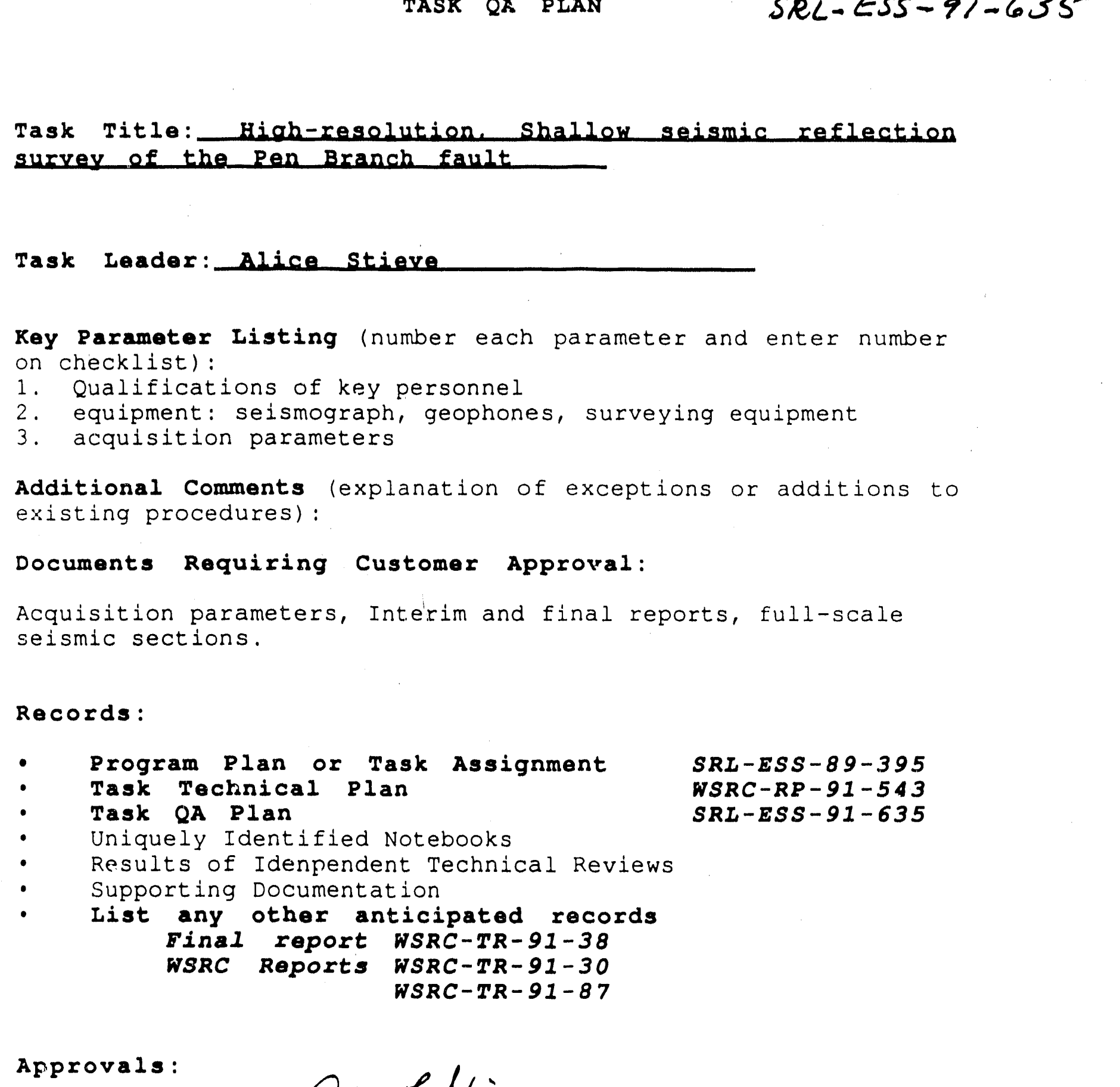



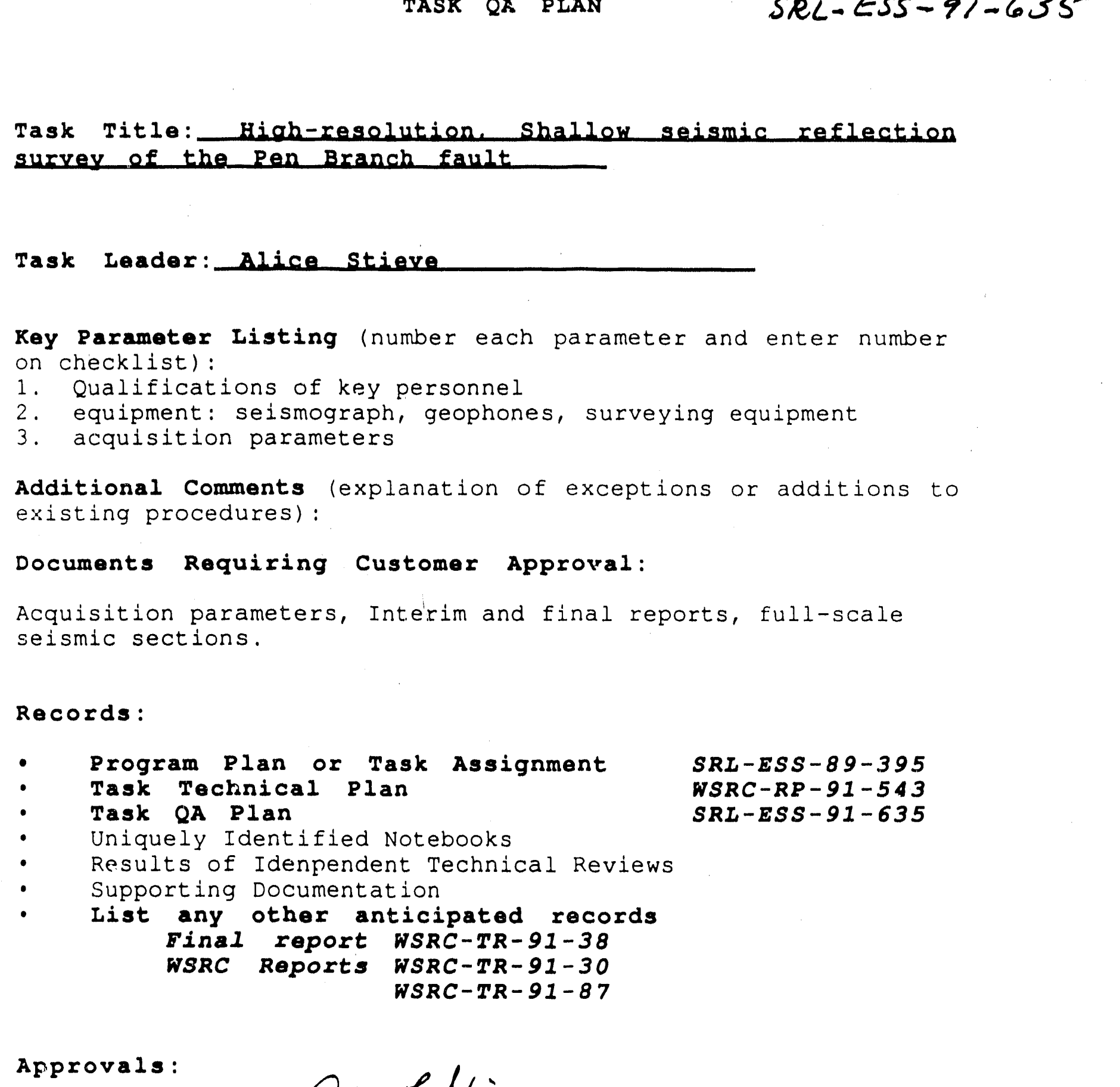

Alice stieve

Min A. Stier

Task Leader

$\frac{\text { Nawn Kaback }}{\text { Group manager }}$

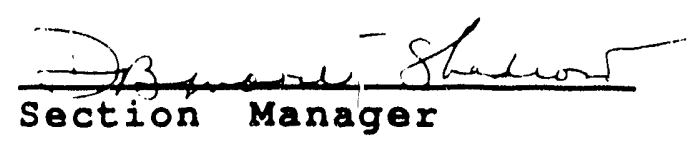

$\frac{S R L_{0} l_{n}}{\text { ougnizant }}$
Date

$6 / 17 / 91$

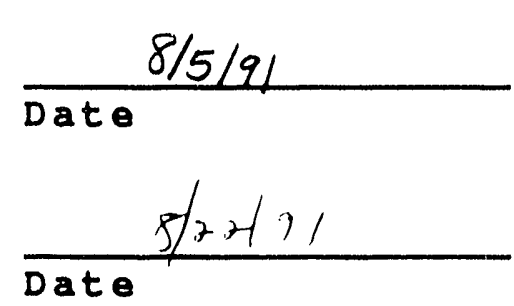

9116191

Date 
Task QA Plan Checklist

Task Title: High-r solution, shallow seismic reflection

Task Leader Alice Stieve

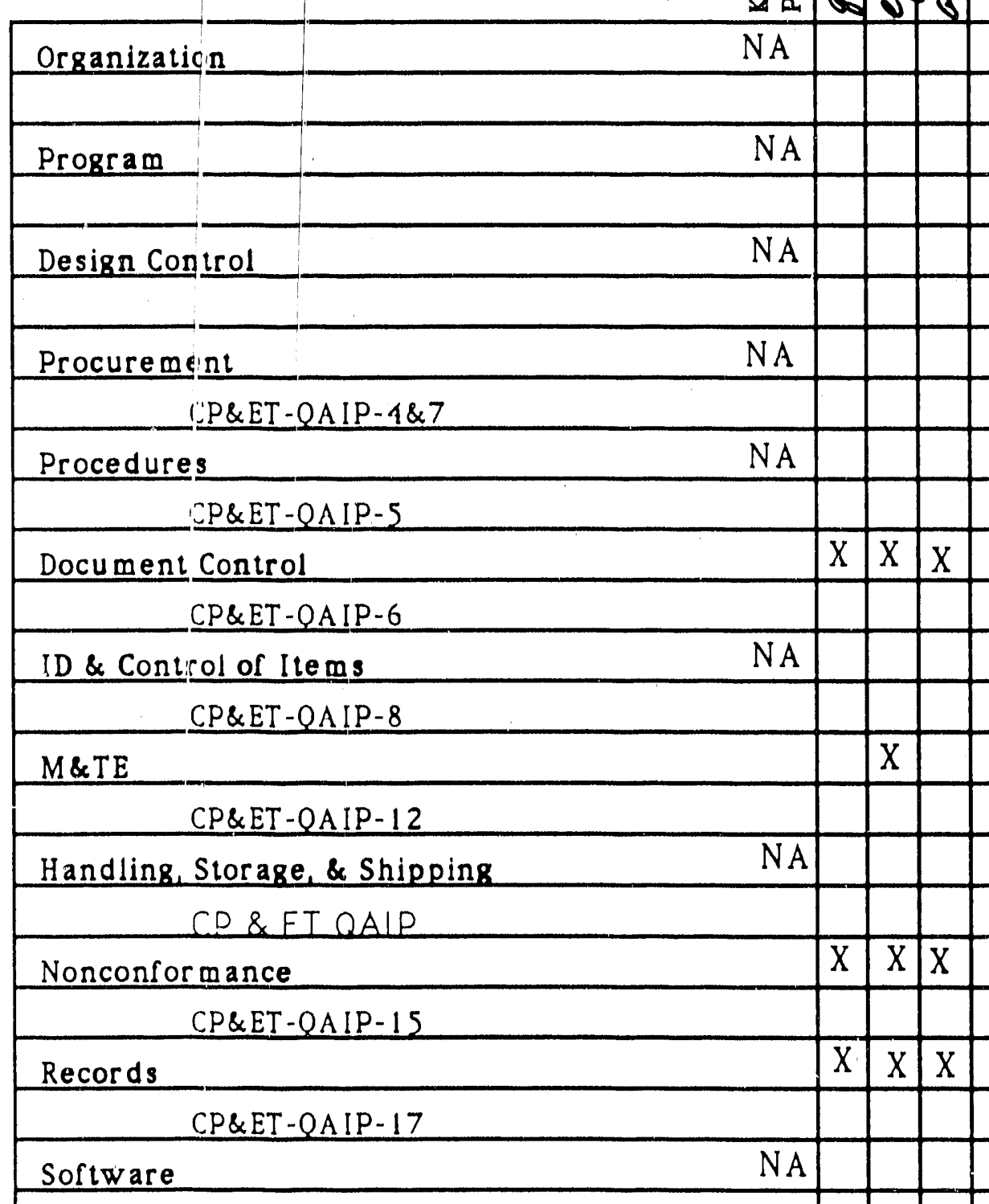






\section{$\Gamma$}

$\rightarrow$
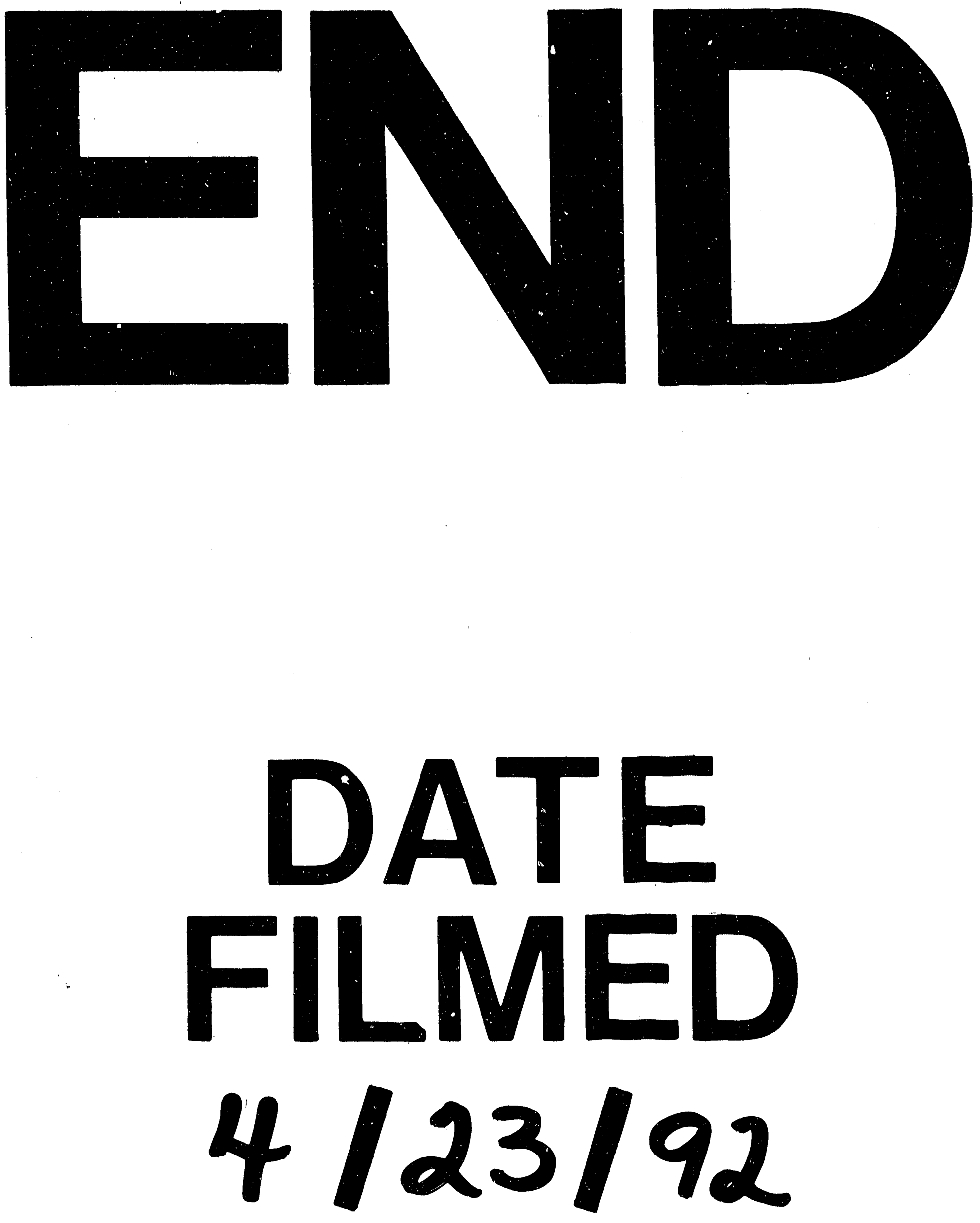

I 
